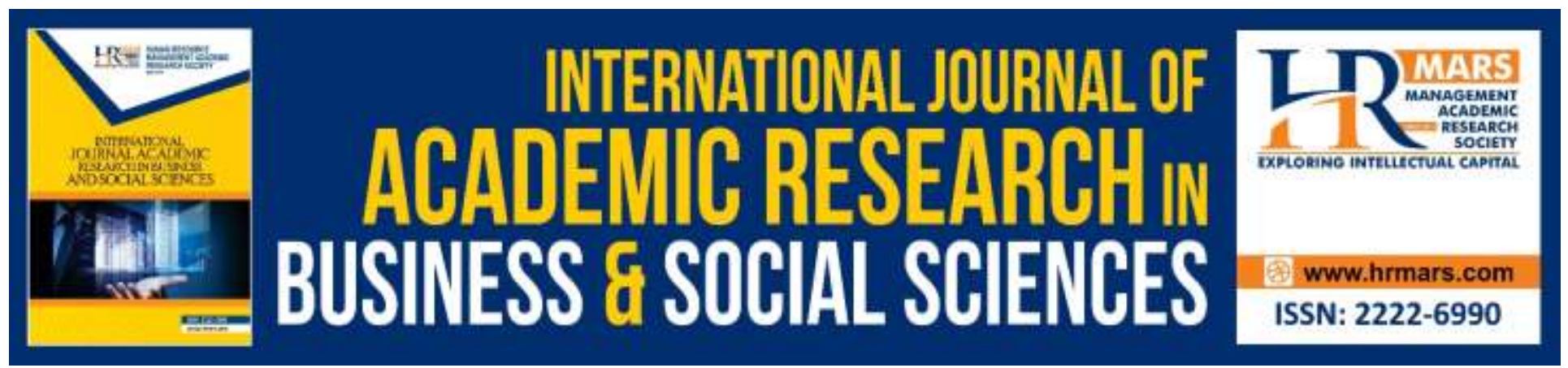

\title{
Proactive Human Resource Management and Improved Employee Quality of Worklife: Incident from Organizations in Southern Nigeria
}

\section{Francis Chidi Alinno}

To Link this Article: http://dx.doi.org/10.6007/IJARBSS/v10-i4/7123

DOI:10.6007/IJARBSS/v10-i4/7123

Received: 06 February 2020, Revised: 07 March 2020, Accepted: 25 March 2020

Published Online: 12 April 2020

In-Text Citation: (Alinno, 2020)

To Cite this Article: Alinno, F. C. (2020). Proactive Human Resource Management and Improved Employee Quality of Worklife: Incident from Organizations in Southern Nigeria. International Journal of Academic Research in Business and Social Sciences, 10(4), 232-253.

Copyright: @ 2020 The Author(s)

Published by Human Resource Management Academic Research Society (www.hrmars.com)

This article is published under the Creative Commons Attribution (CC BY 4.0) license. Anyone may reproduce, distribute, translate and create derivative works of this article (for both commercial and non-commercial purposes), subject to full attribution to the original publication and authors. The full terms of this license may be seen

at: http://creativecommons.org/licences/by/4.0/legalcode

Vol. 10, No. 4, 2020, Pg. 232 - 253

Full Terms \& Conditions of access and use can be found at http://hrmars.com/index.php/pages/detail/publication-ethics 


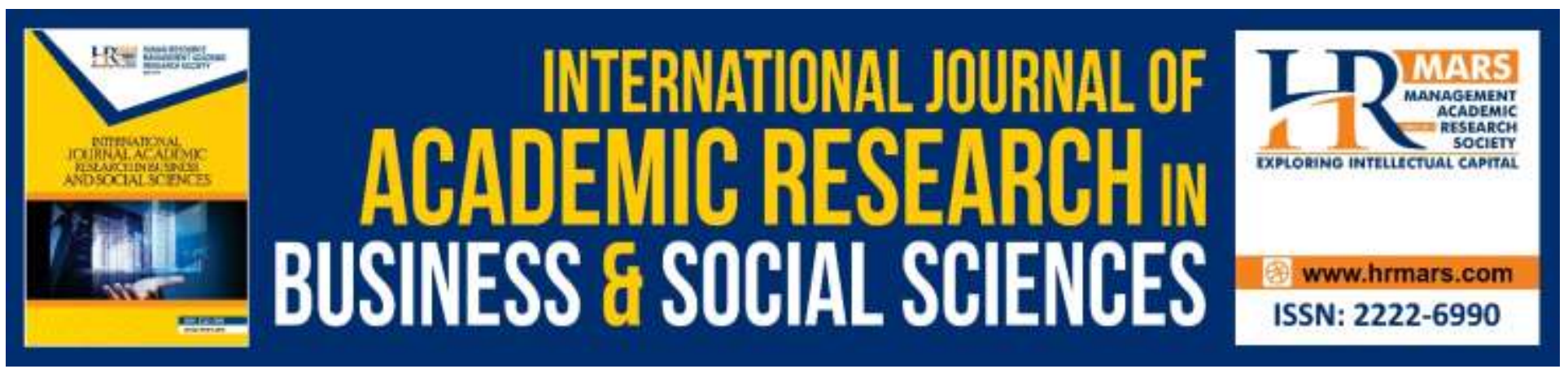

\title{
Proactive Human Resource Management and Improved Employee Quality of Worklife: Incident from Organizations in Southern Nigeria
}

\author{
Francis Chidi Alinno \\ Business Administration and Management Department, School of Business Studies, Akanu Ibiam \\ Federal Polytechnic Unwana, Ebonyi state, Nigeria \\ Email: alinoy2000@yahoo.com
}

\begin{abstract}
The paper focused on how managing human resource proactively has improved employee quality of work life in organizations in Southern Nigeria. Subsequently, data was generated through questionnaire from 653 respondents. Three hypotheses were tested with T-Distribution at 0.05 level of significance. The results shows that managing human resource proactively has made insignificant improvement on employee quality of work life; unsafe work environment, inadequate and unfair compensation, absence of opportunity for personal growth and job security, constant infringement on personal leisure and family needs amongst other factors impedes managing human resource proactively and averts improvement on employee QWL in the organizations and the little improvement in employee QWL has not made any impact on workers attitude to work in organizations in Southern Nigeria. The author observed that there may not be any universal inclination for improving employee QWL because of number of factors, but recommends flexibility in work schedule, creating autonomous work group and enriching the job as a methods of improving employee QWL; making work more satisfying by giving employees freedom of operation and added responsibility as well as opportunity to schedule own work and ensure that job and human behaviour are directly related through work design.
\end{abstract}

Keywords: Proactive, Human Resource, Management, Quality and Work life

\section{Introduction}

Over the last hundred years, management of employee potentials in organizations has been evolving dramatically, usually in response to external conditions. Though human resource management gained momentum during the human relations movement era of the early 20th century (Kaufman, 2001). It was at this point that researchers began documenting ways of creating business value through the strategic management of the workforce (Tubey, 2015). The concept has gone through a 
INTERNATIONAL JOURNAL OF ACADEMIC RESEARCH IN BUSINESS AND SOCIAL SCIENCES Vol. 10, No. 4, April, 2020, E-ISSN: 2222-6990 @ 2020 HRMARS

number of stages and it is still going. The early part of $18^{\text {th }}$ century saw a concern for improved efficiency through careful design of work. During the middle part of the century emphasis shifted to the employee's productivity. Recent decades have focused on increased concern for the quality of working life, total quality management and worker's participation in management. These three phases may be termed as welfare, development and empowerment. These phases were initially dominated by transactional work such as payroll and benefits administration, but due to globalization, company consolidation, technological advancement, and further research, it now focuses on strategic initiatives like mergers and acquisitions, talent management, succession planning, industrial and labour relations, diversity and inclusion (Richard, 2010).

An organized form of HRM emerged during the industrial revolution as the World shifted from an agricultural economy to an industrial economy. Companies were forced to develop and implement effective ways of recruiting and keeping skilled workers (Giri, 2008). Other factors such as hazardous working conditions and pressure from labour unions also increased the importance of effective management of human resource. The manufacturing efficiencies brought about by industrialization came several shortcomings related to working conditions. Employees started seeking and agitating for better deal and improvement in working conditions. Two other important factors which contributed to the emergence of modern human resources management were the industrial welfare movement and Frederick W. Taylor's (1856-1915) Scientific Management that outlined management methods for attaining greater productivity from low-level production workers (Giri, 2008). HRM as a professional discipline was especially bolstered by the passage of the Wagner Act in 1935 (also known as the National Labour Relations Act), which remained the basic U.S. labour law through the 1990 s. It augmented the power of labour unions and increased the role and importance of personnel managers (Karl, 2006).

By 1930s and 1940s, the general focus of HRM changed from a focus on worker efficiency and skills to employee satisfaction. That shift became especially pronounced after World War II, when a shortage of skilled labour forced companies to pay more attention to workers' needs. Influenced by the famous Hawthorne productivity studies and similar research, employers began to emphasize personal development and improved working conditions, as a means of motivating employees (Karl, 2006). In the 1960s and 1970s the USA government furthered the HRM movement with a series of regulations created to enforce fair treatment of workers, such as the Equal Pay Act of 1963, the Civil Rights Act of 1964, the Employee Retirement Income Security Act of 1974 (ERISA), and the Occupational Safety and Health Act of 1970. Because of these acts, companies began placing greater emphasis on HRM in order to avoid lawsuits for violating this legislation. HRM's importance continued to grow during the 1980s for reasons such as changing workforce values which require HRM professionals to adapt organizational structures to a new generation of workers with different attitudes about authority and conformity. Shifting demographics forced changes in the way workers were hired, fired, and managed. Other factors contributing to the emergence of HRM during the 1980s and 1990s were increasing educational levels, growth of service and white-collar jobs, corporate restructuring (including reductions in middle management), more women in the workforce, slower domestic market growth, greater international competition, and new federal and state regulations (Giri, 2008). The prominence of these discussions points to the fact that 
INTERNATIONAL JOURNAL OF ACADEMIC RESEARCH IN BUSINESS AND SOCIAL SCIENCES Vol. 10, No. 4, April, 2020, E-ISSN: 2222-6990 @ 2020 HRMARS

improvement in quality of work life is always upper most in the minds of employees in organizations where they trade their skills.

\section{Statement of Problem}

The Industrial and business environment in Nigeria, broadly speaking does not make for safe work environment. Effective occupational health care, suitable working time, and appropriate salary which are the other major aspects of QWL are also lacking. The safe work environment provides the basis for a person to be happy at work. The work should not pose a health hazard for the person. The employer and employees are aware of their risks and rights, and could achieve a lot for their mutual benefit. The working time has been indicated by the State according to the legislation but enforcement has not been effective. Studies have equally revealed that poor QWL was related to lack of independence to make decisions, increased workload, role conflicts, lack of opportunities for career advancement, low salary, lack of professional autonomy, lack of stakeholders support and insufficient welfare services and they adversely affects the quality of work life. Theoretically business organization in Nigeria, design task and job responsibility, working conditions, employee security, health and safety packages of employees, pay and benefit(s), supervising schedule but practicability have always not been satisfying and these have seriously and negatively affected the attitude of employees in these organizations. It was on these notes that the paper peer into the under listed objectives.

\section{Objectives of the Study}

The following objectives are imperative to this study:

$>$ To determine the extent that proactive human resource management has helped to improve employee quality of work life in selected organizations in Southern Nigeria.

$>$ To find out if there are factors impeding proactive human resource management and so averts improvement in employee QWL in the selected organizations in Southern Nigeria.

$>$ To ascertain whether the improvement in employee QWL if any has made notable impact on employees' attitude to work in the selected organizations in Southern Nigeria.

\section{Research Questions}

$>$ To what extent has proactive human resource management helped to improve employee quality of work life in the selected organizations in Southern Nigeria?

$>$ Are there factors that impede proactive human resource management and avert improvement in employee QWL in the selected organizations in Southern Nigeria?

$>$ Has the improvement in employees' QWL if any made any notable impact on their attitude to work in the selected organizations in Southern Nigeria?

\section{Research Hypotheses}

$>H_{0}$ : Proactive human resource management has made insignificant improvement on employee quality of work life in the selected organizations in Southern Nigeria.

$>H_{0}$ : Unsafe work Environment, Inadequate and unfair compensation, Absence of Opportunity for personal growth and job security, Constant infringement on personal leisure and family needs and Lack of protection for personal privacy, dissent, and due process are the factors 
INTERNATIONAL JOURNAL OF ACADEMIC RESEARCH IN BUSINESS AND SOCIAL SCIENCES

Vol. 10, No. 4, April, 2020, E-ISSN: 2222-6990 @ 2020 HRMARS

that impedes proactive human resource management and avert improvement in employee QWL in the selected organizations in Southern Nigeria.

$>H_{0}$ : The improvement in employees' QWL has not made any notable impact on their attitude to work in the selected organizations in Southern Nigeria.

\section{Conceptual Framework of the Study}

\section{Concept and component of Employee Quality of Work life}

Quality of work life (QWL) is a concept of behavioural science, and the term was first introduced by Davis in 1972 (Mathur, 1989; Hian \& Einstein, 1990). Nadler and Lawler (1983) say QWL is a process by which an organization responds to employees' needs by developing mechanisms to allow them to share fully in making the decisions that affect their lives at work. The key elements of QWL in the literature include job security, job satisfaction, better reward system, employee benefits, employee involvement and organizational performance (Havlovic, 1991; Scobel, 1975).

Jaiswal (2014) remarks that quality of life is sociological and psychological phenomenon. But sociologists are not putting their interest in industrial sector, where the workers are the core potential resource for organizational performance. To Kulkarni (2013) QWL is defined as the favourable conditions and environments of a workplace that support and promote employee satisfaction by providing them with rewards, job security, and growth opportunities. Kulkarni (2013) says QWL is a comprehensive programme designated to improve employees' satisfaction and it is not only concerned with the monetary aspects but also conditions of employment, interpersonal conflicts, job pressure, lack of freedom and absence of challenging work, etc. Kulkarni (2013) concludes that it is a way of thinking about people, work and organization and creates a sense of fulfillment in the minds of the employees and contributes toward greater job satisfaction, improving productivity, adoptability and overall effectiveness of an organization. Maks, Mirvis, Hackett, \& Grady, (1986) observe that there are two kinds of indicators for defining quality of life. One is an objective indicator, for example money and the other is subjective indicator, such as financial status, living standard, job etc. In a nutshell, objective indicators define quality of life in terms of goods while subjective indicators are defined as quality of life as perceived by individuals. Lowe (2001) opines that quality of worklife is not a sum of its component units, quality of worklife is more than interaction, attitude, aspiration, fears, satisfaction or dissatisfaction, and it creates cross cultural similarities and dissimilarities.

Many factors determine the meaning of quality of worklife ( $Q W L$ ), one of which is work environment (Rethinam \& Maimunah, 2008). As the work culture changes drastically in the recent years, the traditional concept of work to fulfill humans' basic needs are also fading out. The basic needs have continued to diversify and change according to the evolution of the work system and standards of living of the workforce (Rethinam \& Maimunah, 2008). The explanation by Suttle (1977) that QWL is the degree to which work is able to satisfy important personal basic needs through their experience in the organization, is no longer relevant. Generally, jobs in the contemporary work environment offer sufficient rewards, benefits, recognition and control to employees over their actions. Although to some extent contemporary workforce are compensated appropriately, their personal spending practices, lifestyles, leisure activities, individual value systems, health and so forth can affect their levels of need. It is similar to the argument posted in the Maslow's hierarchy of needs in which each 
INTERNATIONAL JOURNAL OF ACADEMIC RESEARCH IN BUSINESS AND SOCIAL SCIENCES Vol. 10, No. 4, April, 2020, E-ISSN: 2222-6990 @ 2020 HRMARS

individual has different level of needs because in reality what is important to some employees may not be important to others, although they are being treated equally in the same organization. This definition, focusing on personal needs has neglected the fact that the construct of QWL is subjective and continuously evolves due to an ever growing need of each and every employee.

Hackman and Oldhams (1980) underscore the constructs of QWL in relation to the interaction between work environment and personal needs. The work environment that is able to fulfill employees' personal needs is considered to provide a positive interaction effect, which will lead to an excellent QWL. They emphasized that, the personal needs are satisfied when rewards from the organization, such as compensation, promotion, recognition and development meet their expectations. For instance, Maruthamuthu, Chitra, Pramothine and Surendar (2018), note that a formal leave policy for employees with dependents recognizes and encourages the need to care for sick children or elderly parents. Parallel to this definition, Lawler (1982) characterizes QWL in terms of job characteristics and work conditions. He highlights that the core dimension of the entire QWL in the organization is to improve employees' well-being and productivity. The most common interaction that relates to improvement of employees' well-being and productivity is the design of the job. Job design that is able to provide higher employee satisfaction is expected to be more productive. However, he accepted the fact that QWL is composite, because it comprises physical and mental well being of employees. A definition by Beukema (1987) portrays QWL as the degree to which employees are able to shape their jobs actively, in accordance with their options, interests and needs. It is the degree of power an organization gives to its employees to design their work. This means that the individual employee has the full freedom to design his job functions to meet his personal needs and interests. This definition emphasizes the individual's choice of interest in carrying out the task. However, this definition differs from the former which stresses on the organization that designs the job to meet employees' interest. It is difficult for the organization to fulfill the personal needs and values of each employee. However if the privatized organizations provides the appropriate authority to design work activities to the individual employees, then it is highly possible that the work activities can match their employees' needs that contribute to the organizational performance. In the same vein Heskett, Sasser \& Schlesinger (1997) describe QWL as the feelings that employees have towards their jobs, colleagues and organizations that ignite a chain leading to the organizations' growth and profitability. A good feeling towards their job means the employees feel happy doing work which will lead to a productive work environment. This definition provides an insight that the satisfying work environment is considered to provide better QWL. Proceeding to previous definitions, Lau, Wong, Chan, \& Law (2001) operationalize QWL as the favourable working environment that supports and promotes satisfaction by providing employees with rewards, job security and career growth opportunities. Indirectly the definition indicates that an individual who is not satisfied with reward may be satisfied with the job security and to some extent would enjoy the career opportunity provided by the organization for their personal as well as professional growth.

The recent definition of QWL by Serey (2006) is quite convincing and best meet the modern work environment. The definition is related to meaningful and satisfying work. It includes (i) an opportunity to exercise one's talents and capacities, to face challenges and situations that require independent initiative and self-direction; (ii) an activity thought to be worthwhile by the individuals involved; (iii) 
an activity in which one understands the role the individual plays in the achievement of some overall goals; and (iv) a sense of taking pride in what one is doing and in doing it well. This issue of meaningful and satisfying work is often merged with discussions of job satisfaction, and believed to be more favourable to QWL.

Quality of Work Life (QWL) has become one of the important issues in organizations (Majumder, 2006). In term(s) of working conditions, export-oriented enterprises are supposed to maintain their international standards. However, working conditions are changing by the force of technological advancement. In addition, it has been observed that technology has also changed the work culture in both service and manufacturing enterprises (Mathur, 1989; Ratnam, 2001). Technological innovation in the work process has evidently brought about higher level of product quality and volume of production (Rahman, 2005; Islam, 2002; Yussuf, 2008). The basic philosophy of QWL is in regard to employee learning capability (Camman, 1984) and learning organization environment (Zain, 1999). Otherwise jobs become under threat and insecure, result in an increased level of employee dissatisfaction on work performance. It is well known that employee intrinsic motivation has an impact on organizational performance. Herzberg, Mausner, and Snyderman (1959) had shown that motivated employees tend to perform better. Company needs to find out the factors that influence employees' satisfaction and ensure their quality of work life (Gilgeous, 1998).

In this regard, QWL can simply be defined as the quality of the relationships between employees' life activities outside the work environment and the total working environment. It is seen as a crucial component in working life which facilitates and promotes employees positive attitudes and behaviours in the work environment. Osibanjo, Oyewunmi, Abiodun, and Oyewunmi (2019) remark that all things related to welfare and comfort of employees in work life is known as Quality of work life. The main purpose was to alleviate the challenges militating against quality of employees' life at the workplace. This frees the mind of the employee from worries that serve to take his or her concentration from work, These behaviours represent the fundamental factors for organizational success and customer satisfaction.

\section{Empirical Evaluation of Quality of Work Life}

Zohurul and Siengthai (2009) in their study on Quality of work life and organizational performance: Empirical evidence from Dhaka Export Processing Zone in Bangladesh, measured quality of work life and organizational performance using Herzberg hygiene factor starting with the wage policy affects organizational performance. Wage policy is the core components to measure employees' satisfaction and quality of work life. Organizations as employers set the wages in line with their internal policy and the wages are varied from enterprises to enterprises and from job to job. Though Government has a set of instructional manual which sets the minimum wages, sometimes employers do not follow these instructions but are rather guided by their internal policy framework. Minimum wage is the level of what the least paid employee is entitled to his take home whether on daily, weekly or monthly basis, depending on the payment pattern of the country in question. The higher the minimum wage the better the effect on motivation and high QWL.

Zohir (2007) identified that financial benefit and social welfare, security and leave provisions have positive impact on worker's quality of work life. And these set(s) of benefits have impact on firm 
INTERNATIONAL JOURNAL OF ACADEMIC RESEARCH IN BUSINESS AND SOCIAL SCIENCES Vol. 10, No. 4, April, 2020, E-ISSN: 2222-6990 @ 2020 HRMARS

performance. Zohir, (2007) also notes that non-financial benefit plays positive role for workers quality of life and firm performance. For example, canteen facilities, festival bonus, attendance bonus, transport facilities and wage increment.

Rethinam and Maimunah (2008) in a comparative study on construct of quality of worklife: a perspective of information technology professionals in Putra-Malaysia and Bahrain, found that effective strategic human resource policies and procedures are essential to govern and provide excellent QWL among IT professionals. Conversely, poor human resource strategic measures that are unable to address these issues can effectively distort the QWL, which will eventually fail the organizations' vision of becoming competitive globally or increase performance locally. Tabassum (2012) carried out a study in Bangladesh to determine the interrelations between Quality of Work Life Dimensions and faculty member job satisfaction in the private universities through quantitative survey on 72 full-time faculty members. The study reveals that all the dimensions of QWL are positively correlated with the job satisfaction of faculty members, which indicate that enhancement in the dimensions of QWL can lead to increased amount of job satisfaction, which could as well increase the performance of the private universities. Jena1 and Pradhan (2014) carried a study to investigate the empirical relationship between work place spirituality and work-life balance amongst employees and executives of manufacturing Public Sector industries in Eastern Indian sub-continent. Using purposive random sampling, 206 employees and executives was selected for the study. The researchers found a moderately significant relationship between spiritual competences with work life balance irrespective of demographic profile. The findings have suggested revitalizing both the aspects together for establishing an effective behavioural intervention in an organizational set up. Harish and Subashini (2014) took a study of some Indian industries on quality of work life. The study found that quality of work life encompasses the sum total of healthy experiences that individuals experience in various facets of life. Harish and Subashini (2014) also discovered that a sizable component of the quality of life is the quality of life experienced by organization members at the work place.

Quality of WorkLife (QWL) is a multi-dimensional construct, made up of a number of interrelated factors. It is associated with job satisfaction, job involvement, motivation, productivity, health, safety and well-being, job security, competency development and balance between work and non work life (De Jonge \& Landerweerd, 1993; Hood \& Smith, 1994; European Foundation for the Improvement of Living and Work Conditions, 2002). These authors equally remark that QWL is also viewed as a wideranging concept, which includes adequate and fair remuneration, safe and healthy work conditions and social integration in the work organization that enables an individual to develop and use all his or her capacities.

Considering the nature of work in the contemporary environment, Rethinam and Maimunah (2008) see QWL as the effectiveness of work environment that transmit(s) to meaningful organizational and personal needs in shaping the values of the employees that support and promote better health and well-being, job security, job satisfaction, competency development and balance between work and non-work life which eventually culminate in improved organizational performance.

Sundaray, Sahoo and Tripathy, (2009) examine the impact of employee relations initiative on quality of work life of the employees of TTPS and OPTCL, as well as analyzed the relevance of various 
employee relations measures in improving quality of work life environment in organizations. The study was based on case study method and two major industrial units of power sector in Orissa, which were selected for the study. The selected organizations are Talcher Thermal Power Station (TTPS), a Unit of National Transmission Power Corporation (NTPC), and Orissa Power Transmission Corporation Ltd., (OPTCL), a unit government of Orissa undertaken. The study revealed that the organizations adopted employee relations measures like empowerment and involvement, suggestion schemes, collective bargaining, grievance and conflict management, and union-management relations to improve quality of work life of the employees. As a result of those measures, the performances of the organization have improved significantly and employees became more committed towards their organizations.

The empirical evaluations above show that earlier studies on employee quality of work life concentrated on organizations outside the Nigerian environment and have not looked at employee quality of work life relatively to the anticipatory nature of human resource management. Therefore, this paper was structured to cover up this vacuum.

\section{Theoretical Underpinnings of the Study}

Theory as a coherent statement or set of linked ideas that explains observed facts or phenomena which sets out the laws and principles of something known or observed or a hypothesis confirmed by observation, experiment etc. or a belief that can guide behaviour, has applicative nature in social sciences. Its value precisely lies in its ability to fulfill one primary purpose, which is to explain the meaning, nature, and challenges associated with a phenomenon, often experienced but unexplained in the World around us. Then, we may use that knowledge and understanding to act in more informed and effective ways. In this paper, theory is used to explain how some aspects of human behaviour are organized, thus enabling us to make predictions about such behaviour. Some of the important theories on aspects human behaviour are Maslow's Hierarchy of Needs Theory and Herzberg's TwoFactor Theory. These theories provide a base to explain the concept of quality of work Life in organization.

Abraham Maslow's needs theory depicts the complexity of human nature by describing various levels of human needs and satisfaction. There are five need clusters, which are: Physiological needs, Safety needs, Social needs, Esteem needs and Self actualization needs. These needs are arranged in a hierarchy from the lower needs to higher needs. The physiological needs have to be satisfied before one move up to the social needs and so on. As soon as the lower order needs are satisfied, people seek satisfaction from the higher order needs. As recapitulated in the needs fulfillment theory, a person is satisfied if his needs are fulfilled and he gets what he wants. If he does not get what he wants, he becomes dissatisfied. Employees find greater satisfaction in task, physical and social environments which are able to offer them opportunity for work life improvement.

In Herzberg's two factor theory, mere fulfillment of basic needs is not sufficient for job satisfaction. Man tries to actualize himself in his job. His self actualization needs act as factors of satisfaction. The theory postulates two types of work variables i.e. Satisfiers and dissatisfies. Satisfiers are those things or situations which lead to job satisfaction which include: achievement, recognition, advancement, 
responsibility etc. are things which give high satisfaction. As these are related to the actual content of the job they are known as 'job-content factors' or "motivators."

Dissatisfies are those things or situations that result in job-dissatisfaction. Matters relating to company policy, supervision, salary and working conditions etc. are things that commonly result in dissatisfaction. As these are related to the context in which a person performed the task, they are known as 'job-context factors' or 'hygiene factors.' Though both kinds of factors fulfill the needs of a worker, job-satisfaction results primarily from the 'motivators.' QWL includes adequate and fair compensation, work conditions, opportunity for development and growth, job security, social integration, work life balance, involvement and recognition, and workload.

It is essential for the organization to develop quality relation between its employees and working environment because now-a- days, demands of job creates imbalance between family and work life due to job pressure and conflicting interests. The threat of imbalance in work and non-work life has implications not only on the employees but also on organizations, governments and society (Grzywacz and Marks, 2000 in Chakraborty, Chatterjee \& Saha, 2019); Swanson, Power and Simpson, 1998 in 1noufal \& Shani, 2019). Supporting this view, Sari, Bendesa and Antara (2019), observe that QWL is achieved if employees get job satisfaction, both in participating in decision making, as well as in having opportunities to develop.

\section{Methodology}

The paper adopted the survey research design, while stratified sampling method was used to select the sample population of 29 organizations with staff strength of 71291 from eight nine (89) organizations located at the South Eastern part of Nigeria (see appendix 1\& II sample frame). From the 71291 staff of the selected organizations 653 respondents were derived using Cochoran's formula (see appendix III for details). The validity of on the data collection instruments was done by ten seasoned research experts. They ensured that the research instruments (the questionnaire) covered the objectives of the paper thereby achieving the content and face validity of the instruments. The reliability of the instrument was achieved by Test-Retest method and the data obtained was subjected to further manipulation using Spearman's Rank-order correlation formula. The co-efficient of reliability of 0.98 obtained indicate that the instrument was highly reliable (see appendix IV). The questionnaire was structured on a five 5 point rating scale. Therefore, the responses are Strongly Agree (AG)5 points, Agree (A)4 points, Disagree (DA)3 points, Strongly Disagree (SDA)2 point and Unsure (US)1 point. Analysis of data was by mean average and so any variable with mean score of 3.5 and above was accepted while any variable with a mean score below 2.5 was rejected.

\section{Data Analysis Question Distribution}

Out of 653 questionnaire distributed, 627 representing $96 \%$ of the total questionnaire shared were correctly filled and returned. This $96 \%$ representing 627 of the respondents is what was actually used for the study. Tables and mean score were used to present and analyze the data generated. 
INTERNATIONAL JOURNAL OF ACADEMIC RESEARCH IN BUSINESS AND SOCIAL SCIENCES Vol. 10, No. 4, April, 2020, E-ISSN: 2222-6990 @ 2020 HRMARS

\section{Analysis of Respondents Characteristics}

Implicit in this study is the fact that respondents' behaviour and answers on the survey questions are influenced by their unique qualities. These qualities include their age, gender, civil status, educational attainment, and length of stay in the companies.

A look at the age bracket of the respondents revealed that $51 \%$ of the respondents aged between 33years and above, 31\% aged between 28 to 32 years, 15\% aged between 23 to 27 years, while the least of $3 \%$ is within the age bracket of $18-22$ years. This means that a considerable number of the respondents were among the young adult members of the population. In terms of sex distribution, male respondents are $74 \%$ while the female respondents are $26 \%$. On education, respondents with tertiary qualification ranked highest with $84 \%$ cumulative, followed by those with secondary education ranking $16 \%$. This showed that most of the respondents had formal education and can read and write and so can be able to contribute to the study. For length of service, it was observed that the highest percentage $16 \%$ of the respondents have served the organization for between 1-5 years while $21 \%$ have worked with the organization for $6-10$ years, $28 \%$ have served the organization for 11 to 15 years, the remaining 35\% have been with the organization for 16 to 20 years. The highest percentage of participants in the study have great length of time in the organizations studied and stand a better chance of contributing meaningfully to the study. On designation of respondents, $16 \%$ of the respondents are within the rank of Top management team, $22 \%$ are within the rank of branch managers and departmental heads, while $28 \%$ are within the rank of administrative officers. The remaining $34 \%$ is made up of clerks and shop floor staff. This indicates that a good number of the respondents are knowledgeable about "proactive HRM and quality of worlife".

This section focused on analyzing response of research participants on the subject matter. The analysis was based on mean score rating using data collected through the Likert five point scales weighted questionnaire.

From the mean rating in table 4.1, (see appendix I) options 1, 2 and 3 were accepted, while options 4 and 5 were rejected. This indicates that proactive human resource management has made very little and insignificant improvement on employee quality of work life in the selected organizations in Southern Nigeria. Options 4 and 5 support this conclusion from a different angle. Critical evaluation of an average organization in Nigeria reveals that financial benefit are unfair and not equitable and social welfare is lacking, security of job not assured, safety and health of employees are not seen as component of employee benefits as they are exposed to all manner of risks at their work place, no opportunity for workers to use their skills, abilities and initiative in planning and implementing the work, some employees are denied the opportunity for career progression for expressing their mind on issues that affects their work, some employees are required to work for late hours, some are frequently transferred while some do a lot of travelling as a part of their duty and leave provisions which have positive impact on worker's quality of work life is lacking, this is replicated in most organizations studied.

The mean score rating in table 4.2 (see appendix II), revealed that options 1, 2, 3, 4 and 5 were all accepted. This implies that Unsafe work Environment, Inadequate and unfair compensation, Absence of Opportunity for personal growth and job security, constant infringement on personal leisure and 
INTERNATIONAL JOURNAL OF ACADEMIC RESEARCH IN BUSINESS AND SOCIAL SCIENCES Vol. 10, No. 4, April, 2020, E-ISSN: 2222-6990 @ 2020 HRMARS

family needs, lack of protection for personal privacy, dissent, and due process are the major factors impeding proactive human resource management and therefore avert improvement in employee QWL in organizations in Southern Nigeria. These core issues in employee quality of work life, are not even given any form of consideration in most of the organizations studied.

The outcome of the mean score rating in table 4.3 (see appendix III), show that all the options were rejected. This uncovered the fact that no reasonable improvement has been made on the quality of work life of the employees. But if there is any, it is scarcely noticed and has not touched the life of the employees to the extent that it can change their feeling about the organization. Therefore, their attitudes toward the organization remain unsatisfied. As such relationships between workers, between workers and managers are lost to bitterness and acrimony. The workers develop low morale in their work, lateness and absenteeism from work become the order of the day while some act care freely about work assigned to them, some even practice soldiering (the act of feigning to work), pointing to the fact that they are not satisfied with their job. All these boils down to the fact that the improvement on employees' QWL has not made change on their attitude to work in most of the organizations in Southern Nigeria.

\section{Test of Hypotheses}

\section{Statement of Hypothesis 1}

$\boldsymbol{H}_{\mathbf{0}}$ : Proactive human resource management has not made significant improvement on employee quality of work life in the selected organizations in Southern Nigeria.

$H_{1}$ :Proactive human resource management has made significant improvement on employee quality of work life in the selected organizations in Southern Nigeria significantly.

Level of Significant: $\alpha=0.05$

Test Statistic: To check for the significant impact of the variables under estimation we adopted TDistribution Analysis to estimate for inference.

Rejection Rule: Reject $H_{0}$ if $t_{c a l}>t_{t a b}$, otherwise accept or Reject $H_{0}$ if Sig - value $<\alpha=$ 0.05

SPSS OUTPUT FOR T-DISTRIBUTION

\section{One-Sample Test}

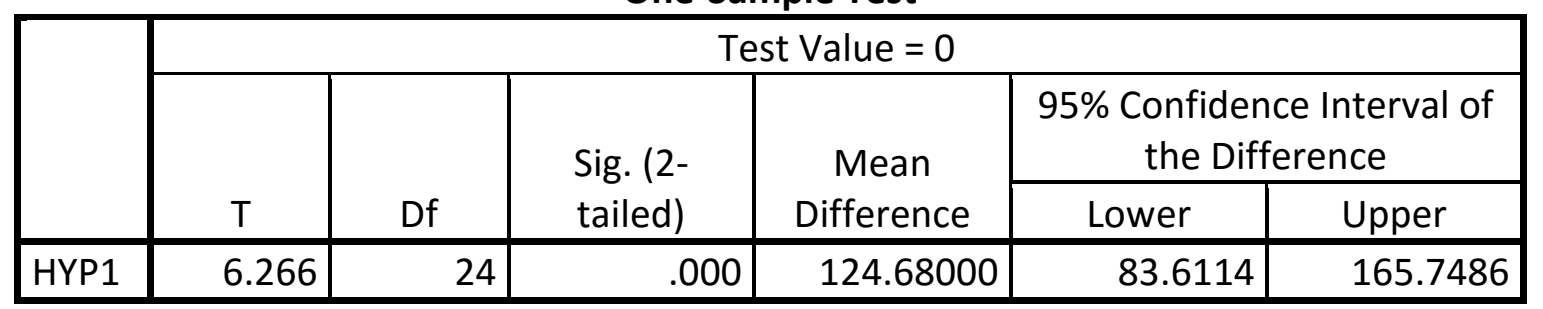

\section{Interpretation of Result}

Based on the SPSS output above, we do have sufficient evidence to reject the null hypothesis $\left(\boldsymbol{H}_{\mathbf{0}}\right)$ and accept the alternative $\left(\boldsymbol{H}_{\mathbf{1}}\right)$, since Sig - value $=0.000<\alpha=0.05$. Therefore, we conclude 
INTERNATIONAL JOURNAL OF ACADEMIC RESEARCH IN BUSINESS AND SOCIAL SCIENCES Vol. 10, No. 4, April, 2020, E-ISSN: 2222-6990 C 2020 HRMARS

that proactive human resource management has made insignificant improvement on employee quality of work life in the selected organizations in Southern Nigeria.

\section{Statement of Hypothesis 2}

$1 H_{0}$ :There are no factors impeding proactive human resource management and that avert improvement on employee QWL in organizations in Southern Nigeria.

$2 \quad H_{1}$ : Unsafe work Environment, Inadequate and unfair compensation, Absence of Opportunity for personal growth and job security, Constant infringement on personal leisure and family needs and Lack of protection for personal privacy, dissent, and due process are the factors that impedes proactive human resource management and avert improvement on employee QWL in the selected organizations in Southern Nigeria..

Level of Significant: $\alpha=0.05$

Test Statistic: To test the validity of the hypothesis we adopted one sample T-test.

Rejection Rule: Reject $H_{0}$ if $t_{c a l}>t_{t a b}$, otherwise accept or Reject $H_{0}$ if $P-$ value $<\alpha=0.05$ SPSS OUTPUT

One-Sample Statistics

\begin{tabular}{|l|r|r|r|c|}
\hline & $\mathrm{N}$ & Mean & \multicolumn{1}{c|}{$\begin{array}{c}\text { Std. } \\
\text { Deviation }\end{array}$} & $\begin{array}{c}\text { Std. Error } \\
\text { Mean }\end{array}$ \\
\hline $\begin{array}{l}\text { Data } \\
2\end{array}$ & 5 & 4.0180 & .10826 & .04841 \\
\hline
\end{tabular}

\section{One-Sample Test}

\begin{tabular}{|c|c|c|c|c|c|c|}
\hline & \multicolumn{6}{|c|}{ Test Value $=0$} \\
\hline & \multirow[b]{2}{*}{$\mathrm{T}$} & \multirow[b]{2}{*}{ Df } & \multirow{2}{*}{$\begin{array}{l}\text { Sig. }(2- \\
\text { tailed) }\end{array}$} & \multirow{2}{*}{$\begin{array}{c}\text { Mean } \\
\text { Difference }\end{array}$} & \multicolumn{2}{|c|}{$\begin{array}{l}95 \% \text { Confidence Interval of } \\
\text { the Difference }\end{array}$} \\
\hline & & & & & Lower & Upper \\
\hline $\begin{array}{l}\text { Data } \\
2\end{array}$ & 82.991 & 4 & .000 & 4.01800 & 3.8836 & 4.1524 \\
\hline
\end{tabular}

\section{Interpretation of Result}

Based on the data before me there is sufficient evidence to reject the null hypothesis and accept the alternative since $P-$ value $=0.000<\alpha=0.05$ at 2-tail test. Therefore, we conclude that unsafe work Environment, inadequate and unfair compensation, absence of opportunity for personal growth and job security, constant infringement on personal leisure and family needs and lack of protection for personal privacy, dissent, and due process are the factors that impedes proactive human resource management and avert improvement on employee QWL in the selected organizations in Southern Nigeria.

\section{Statement of Hypothesis 3}

1. $\quad \boldsymbol{H}_{\mathbf{0}}$ : The improvement in employees' QWL has not made any notable impact on their attitude to work in the selected organizations in Southern Nigeria.

2. $\quad \boldsymbol{H}_{\mathbf{1}}$ :The improvement in employees' QWL has made some notable impact on their attitude to 
INTERNATIONAL JOURNAL OF ACADEMIC RESEARCH IN BUSINESS AND SOCIAL SCIENCES

Vol. 10, No. 4, April, 2020, E-ISSN: 2222-6990 @ 2020 HRMARS

work in the selected organizations in Southern Nigeria.

Level of Significant: $\alpha=0.05$

Test Statistic: To check for the significant impact of the variables under estimation we adopted T-

Distribution Analysis to estimate for inference.

Rejection Rule: Reject $H_{0}$ if $t_{c a l}>t_{t a b}$, otherwise accept or Reject $H_{0}$ if Sig - value $<\alpha=$ 0.05

SPSS OUTPUT FOR T-DISTRIBUTION

One-Sample Test

\begin{tabular}{|c|c|c|c|c|c|c|}
\hline & \multicolumn{6}{|c|}{ Test Value $=0$} \\
\hline & \multirow[b]{2}{*}{$\mathrm{T}$} & \multirow[b]{2}{*}{ Df } & \multirow{2}{*}{$\begin{array}{l}\text { Sig. }(2- \\
\text { tailed) }\end{array}$} & \multirow{2}{*}{$\begin{array}{c}\text { Mean } \\
\text { Difference }\end{array}$} & \multicolumn{2}{|c|}{$\begin{array}{l}\text { 95\% Confidence Interval of } \\
\text { the Difference }\end{array}$} \\
\hline & & & & & Lower & Upper \\
\hline HYP3 & 5.685 & 24 & .080 & 125.36000 & 79.8473 & 170.8727 \\
\hline
\end{tabular}

\section{Interpretation of Result:}

Based on the SPSS output above, we have no sufficient evidence to reject the null hypothesis $\left(\boldsymbol{H}_{\mathbf{0}}\right)$ and accept the alternative $\left(\boldsymbol{H}_{\mathbf{1}}\right)$, since Sig - value $=0.080>\alpha=0.050$. Therefore, we conclude that the improvement in employees' QWL has not made any notable impact on their attitude to work in the selected organizations in Southern Nigeria.

\section{Summary of Major Findings}

It was found that managing human resource proactively has made very little and insignificant improvement on employee quality of work life in the selected organizations in Southern Nigeria.

The study discovered that unsafe work Environment, inadequate and unfair compensation, absence of opportunity for personal growth and job security, constant infringement on personal leisure and family needs, lack of protection for personal privacy, dissent, and due process are the major factors impeding proactive human resource management and therefore avert improvement in employee QWL in organizations in Southern Nigeria.

The study further revealed that the little and insignificant improvement in employees' QWL has not made any notable impact on their attitude to work in the selected organizations in Southern Nigeria.

\section{Discussion of major Findings}

Result of data analysis on table 4.1 (see appendix 1) and result of the test of hypothesis one, revealed that proactive human resource management has made very little and insignificant improvement on employee quality of work life in the selected organizations in Southern Nigeria. Critical assessment of an average organization in Nigeria reveals that financial benefit are unfair and inequitable, social welfare is lacking, security of job not assured, safety and health of employees are not seen as component of employee benefits as they are exposed to all manner of risks at their work place, no opportunity for workers to use their skills, abilities and initiative in planning and implementing the work, some employees are denied the opportunity for career progression for expressing their mind 
on issues that affects their work, some employees are required to work for late hours, some are frequently transferred while some do a lot of travelling as a part of their duty and leave provisions which have positive impact on worker's quality of work life is lacking, this is replicated in most organizations in southern Nigeria studied.

Result of data analysis on table 4.2 (see appendix 11) and result of the test of hypothesis two, revealed that unsafe work Environment, inadequate and unfair compensation, absence of opportunity for personal growth and job security, constant infringement on personal leisure and family needs, lack of protection for personal privacy, dissent, and due process are the major factors impeding proactive human resource management and therefore avert improvement in employee QWL in organizations in Southern Nigeria. These core issues in employee quality of work life are not even given any form of consideration in most of the organizations studied.

This is why the Federal Ministry of Labour and Employment in collaboration with the International Labour Organization (ILO) in 2016 took the step to develop a baseline National Occupational Safety and Health Profile to stimulate effective management of safety and health at work in Nigeria, information from personal interview with key respondent show that the law made provision for fair and adequate compensation for employees at work place but the level corruption in the system has made it almost impossible for employee entitled to such compensation to enjoy it.

Result of data analysis on table 4.3 (see appendix 111) and result of the test of hypothesis three show that the little and insignificant improvement in employees' QWL has not made any notable impact on their attitude to work in the selected organizations in Southern Nigeria studied. Quality in the work life of the employees in the organizations in Southern Nigeria is scarcely noticed and has not touched the life of the employees to the extent that it can change their feeling about their organizations. Therefore, their attitudes toward the organization remain unsatisfied. As such relationships between workers, between workers and managers are lost to bitterness and acrimony. The workers develop low morale in their work, lateness and absenteeism from work become the order of the day while some act care freely about work assigned to them, some even practice soldiering (the act of feigning to work), pointing to the fact that they are not satisfied with their job. All these boils down to the fact that the improvement on employees' QWL has not made change on their attitude to work in most of the organizations in Southern Nigeria.

\section{Conclusion}

It has come to fore that financial benefits in organizations in Southern Nigeria are unfair and inequitable, social welfare is equally lacking, security of job is not assured, safety and health of employees are not seen as component of employee benefits; employees have no opportunity to use their skills, abilities and initiative in planning and implementing their work, some are denied the opportunity for career progression for expressing their mind on issues that affects their work, some are required to work for late hours and are frequently transferred while some do a lot of travelling as a part of their duty. Leave provisions which have positive impact on their quality of work life is lacking, work environment is unsafe, job is not secured, there is constant infringement on employees personal leisure and family needs, personal privacy are not assured. Obviously, there is little or no improvement in employee QWL in these organizations. Therefore, the attitudes of the employees 
remain unsatisfied. As such relationships between and amongst workers, between workers and managers are lost to bitterness and acrimony. The workers develop low morale in their work, lateness and absenteeism from work become the order of the day while some act care freely about work assigned to them, some even practice soldiering (the act of feigning to work), pointing to the fact that they are not satisfied with their job. The situation is made worst by the fact that the economy is filled with multitude of white collar job seekers who are ready to accept anything as salary and so employers see it as an opportunity and care less about how satisfied the employees are with their work. These has rubbed off on the performance of the organizations as most them are found wanting in the global competitive arena.

Employee quality of work life studies in relation to the anticipatory nature of human resource management has never been given its pride of place in research efforts in Nigerian environment. Again, organization in Nigeria has not deemed it necessary to develop quality relationship between employees and working environment. They also lose sight of the fact that job demands creates imbalance between family and work life due to job pressure and conflicting interests, as well as the fact of threat of imbalance in work and non-work life which has implications not only for the employees but also for organizations, governments and society. This paper call attention to these issues and to the fact that complexity of human nature as depicted in Abraham Maslow's needs theory and Herzberg's two factor theory is enmeshed in levels of human needs and satisfaction.

\section{Recommendations}

On these, the author notes and recommends that though there may not be any universal leaning for improving employee QWL because of number of factors, but some more common practices adopted for the purpose are: i) Flexibility in work schedule which may be three aspects, i.e. flexitime- a system of flexible working hours and compressed work week. The extent that this flexibility is provided in the work system becomes source of motivation to the employees,

ii) Autonomous work group which involve freedom of employees to choose their own teams, freedom of decision making regarding the choice of methods for work and freedom of distribution of tasks among group members and designing of work schedules which helps in creating positive feelings among employees,

iii) Flexibility in work schedule Autonomous work group Job Enrichment which attempts to design a job in such a way that it becomes more interesting and challenging so that the employee makes meaning out of their work. The degree of job enrichment determines the degree of QWL; opportunity for growth which involves employee, particularly the achievement-oriented ones, seeks growth through their work. So if the work provides such employees opportunity for personal growth and to develop their personality, they will feel committed to the job and the organization; participation which involves giving employees opportunity to participate in decision making, particularly on the matters directly concerned with their work has important bearing on their satisfaction and performance. A higher degree of participation increases the QWL and overall organizational climate and communication here involves the employees receiving information about the various aspects of the organization which is down ward communication and employees having opportunity to share their views, grievances and make suggestions for improving the work performance which is up ward communication. These helps make QWL sound and possibly reflect on the performance of the organizations. 
Employee(s) work must be made more satisfying by giving them freedom of operation and added responsibility as well as opportunity to schedule own work in order to enhance their sense of achievement and motivation. Giving employee opportunities to schedule own work offers them opportunity to create leisure time and time to share with their families. Giving employee(s) work that makes it difficult for them to have time for their families must be avoided.

Managers of organization in Southern Nigeria must ensure that job and human behaviour are directly related through work design. This will bring about job satisfaction and eventual outcome of less resentment and a more positive attitude to work. These positive attitudes reinforce behaviour which is desirable and more lasting. Work redesign makes the organization a people oriented one and people experience feelings of worth, personal growth and development and aspire for higher levels needs such as self-esteem and self-actualization. Leave provision and implementation which gives employee opportunity to share memorable time with their families make the employee happy and more relaxed at work. The end result is improvement on the performance of the employees which results to improvement on organizational performance.

\section{References}

Journal

Beukema, L. (1987). "Quality of reduction of working hours", in Suzanne, E.J. Arts, Ada Kerkstra, Jouke Van Der Zee, and Huda Huyer Abu Saad, (eds.) (2001) Quality of Working Life and Workload in Home Help Services: A Review of the Literature and a Proposal for a Research Model. Scandinavian Journal of Caring Society, 15(2), 12-24.

De Jonge, J., \& Landeweerd, A. (1993). "Toetsing van de job demand control banadering bij werjnemers in de gezondheidszorg [Testing the job demand - control approach among employees in health care]". Gedrag en Organisatie, 21, 79-92. In Suzanne, E.J., Arts, A., Kerkstra, V.Z., Jouke, \& Abu Saad, H. H. (2001). Quality of working life and workload in home help services: A review of the literature and a proposal for a research model. Scandinavian Journal of Caring Society, 15(4).

Gilgeous, V. (1998). "Manufacturing managers: their quality of working life", Integrated Manufacturing System, 9(3), 173-181.

Grzywacz, J. G., \& Marks, N. F. (2000). "Reconceptualizing the Work-Family Interface: an Ecological Perspective on the correlates of Positive and Negative Spillover between Work and Family".. Journal of occupational health psychology, 5 (1), 111-126. in Chakraborty, T., Chatterjee, B. \& Saha, R. (March, 2019). "Quality of Work Life, Revisiting through Job Satisfaction" East African Scholars Journal of Economics, Business and Management, 2(3).

Harish, K., \& Subashini, K. (2014). "Quality of Work Life in Indian Industries -A Case Study". International Journal of Innovative Research in Science, Engineering and Technology. 3(10),.

Havlovic, S. J. (1991). "Quality of work life and human resource outcomes", Industrial Relations, 30(3), 469-479.

Hian, C. C., \& Einstein, W. O. (1990). “Quality of work life (QWL): What can unions do? S.A.M. Advanced Management Journal, 55(2), 17-22. 
INTERNATIONAL JOURNAL OF ACADEMIC RESEARCH IN BUSINESS AND SOCIAL SCIENCES Vol. 10, No. 4, April, 2020, E-ISSN: 2222-6990 @ 2020 HRMARS

Hood, J. N., \& Smith, H. L. (1994). "Quality of work life in home care". Journal of Nursing Administration, Vol. 24.

Kaufman, B. E. (2001). "Human resources and industrial relations: Commonalities and differences". Human Resource Management Review. 11(4), 339-374.

Kulkarni, P. P. (2013). "A Literature Review on Training \& Development and Quality of Work Life". International Refereed Research Journal. IV2).

Maks, M. I. P. H., Mirvis, E. J. H., \& Grady, J. F. Jr. (1986). “Employee Participation in Quality Circle Programme: Impact on Quality of Work life, Productivity, and Absenteeism", Journal of Applied Psychology, 71(2), 61-69.

Maruthamuthu, D., Chitra, S., Pramothine, G., and Surendar, G. (2018). "Work-Life Balance: Stress and Performance". Journal of Business Management (ISSN: 2455-6661), 4(2), 32-39. Retrieved from https://www.ijrdo.org/index.php/bm/article/view/1849

Nadler, D. A., \& Lawler, E. E. (1983). “Quality of Work Life: Perspectives and Directions”, al dynamics, 11(3), 20-30.

Osibanjo, O. A., Oyewunmi, A. E., Abiodun, A. J., and Oyewunmi, O. A. (2019). Quality of Work-life and Organizational Commitment Among Academics in Tertiary Education. International Journal of Mechanical Engineering and Technology (IJMET), (10)2, 418-430, retrieved from http://www.iaeme.com/ijmet/issues.asp?JType=IJMET\&VType=10\&IType=2 ISSN Print: 0976-6340 and ISSN Online: 0976-6359

Rahman, M. A. (2005). "Sub-contracting Programme of Bangladesh Small and Cottage Industries Corporation (BSCIC)-An Overview", Pakistan Journal of social Sciences, 3(6), 892-897.

Rethinam, G. S., \& Maimunah, R. I. (2008). "Constructs of Quality of Work Life: A Perspective of Information and Technology Professionals", European Journal of Social Sciences, 7(1), 1-2.

Richard M. V. (2010). "The Evolution of HR: Developing HR as an Internal Consulting", Human Resource Planning, Mirage Resorts, MGM MIRAGE, 30(3), ii.

Sari, N. R., Bendesa, I. G., \& Antara, M. (2019). The Influence of Quality of Work Life on Employees' Performance with Job Satisfaction and Work Motivation as Intervening Variables in Star-Rated Hotels in Ubud Tourism Area of Bali. Journal of Tourism and Hospitality Management, 7(1), 74-83 ISSN: 2372-5125, DOI: 10.15640/jthm.v7n1a8 URL: https://doi.org/10.15640/jthm.v7n1a8

Scobel, D. N. (1975). "Doing away with the factory blue”, Harvard Business Review, 53(6), 132-142.

Serey, T. T. (2006). "Choosing a Robust Quality of Work Life", Business Forum, 27(2), 7-10.

Swanson, V., Power, K. G., \& Simpson, R. J. (1998). Occupational stress and family life: A comparison of male and female doctors. Journal of Occupational and Organizational Psychology, 71, 237260.in 1noufal.K.T, \& Shani, N. (January, 2019). Quality of work life: An Exploratory Literature Reviews, International Journal for Innovative Research In Multidisciplinary Field 5(1), 20-24.

Tabassum, A. (2012). "Interrelations between Quality of Work Life Dimensions and Faculty Member Job Satisfaction in the Private Universities of Bangladesh". European Journal of Business and Management. 4(2), 7881.

Tubey R., Rotich, K. J., \& Kurgat, A. (2015). "History, Evolution and Development of Human Resource Management: A Contemporary Perspective". European Journal of Business and Management. 7(9). Retrieved from www.iiste.org on 23rd October, 2019. 
INTERNATIONAL JOURNAL OF ACADEMIC RESEARCH IN BUSINESS AND SOCIAL SCIENCES

Vol. 10, No. 4, April, 2020, E-ISSN: 2222-6990 C 2020 HRMARS

\section{Text Book}

Camman, C. (1984). Productivity of Management Through QWL Programmes, in Frombun, Editor, Strategic Human Resource Management, New York: Wiley, 81.

Hackman, J. R., \& Oldham, G. R. (1980). Work Redesign. Reading, M.A: Addison-Wesley, 95.

Herzberg, F., Mausner, B., \& Snyderman, B. (1959). The Motivation to Work, (2nd ed.) 209.

Heskett, J. L., Sasser, W. E. Jr., \& Schlesinger, L. A. (1997). The service profit chain, New York: The Free Press, 16-20.

Majumder, P. P., \& Begum, A. (2006). Engendering Garment Industry, Bangladesh: The University Press Limited, Dhaka 1000, 91.

Ratnam, C. S. V. (2001). Globalization and Labour-Management Relations: Dynamics of Change, New Delhi: Sage Response Books, 42-54.

Suttle, J. L. (1977). Improving Life at Work: Problem and Prospects. In Hackman, H. R. and Suttle, J. L (eds) Improving Life at Work: Behavioural Science approaches to a change, Santa Barbara, CA: Goodyear, 1-29.

\section{Web Material}

European Foundation for the Improvement of Living Conditions (2002). "New work organization, working conditions and quality of work: towards the flexible firm?" [Online].European Foundation for the Improvement of Living and Working Condition.Luxembourg: Office for Official Publications of the European Communities: Ireland .Available:wwweurofound.eu.int

Giri, Y. L. (2008). Human Resource Management: Managing People at Work. Pune: Nirali Parakashan. Retrieved from https://books.google.com.ng/

Jaiswal, A. (2014). "Quality of work life". Journal of Business Management \& Social Sciences Research, 3(2). Retrieved from www.borjournals.com/a/index.php/jbmssr/

Karl, H. (2006). "Human Resource Management (HRM)". http://www.referenceforbusiness.com/ encyclopedia/Gov-Inc/

\section{Theses}

Islam, N., (2002). "The Impact of Global Technological Change on Textile and Garment Workforce: A Comparative Study of Bangladesh and Thailand", A Doctoral Dissertation, School of Management, Asian Institute of Technology, Thailand, 103.

\section{Conference/Seminar Paper}

Lowe, G. S. (2001). "Quality of Work-Quality of Life”, Canadian Policy Research Network, Conference Key Note Paper, 14 May, 88.

Yussuf, A. A. (2008). "Export Processing Zones (EPZs) in Bangladesh: An Attractive Investment Destination", Executive Chairman Report, dated on. 1-5.

Zain, A. Y. (1999). "An instrument to measure the perceived importance of quality of work life factors: Development of Psychometric Assessment," 3rd Asian Academic of Management Conference, 16-17 July, Malaysia. 33-45.

Zohir, S. C. (2007). "Role of Dhaka Export Processing Zone: Employment and Empowerment", Research Report, Bangladesh Institute of Development Studies, Dhaka, 11-15. 
INTERNATIONAL JOURNAL OF ACADEMIC RESEARCH IN BUSINESS AND SOCIAL SCIENCES

Vol. 10, No. 4, April, 2020, E-ISSN: 2222-6990 @ 2020 HRMARS

Islam, Z. M. D., \& Siengthai, S. (2009). "Quality of work life and organizational performance: Empirical evidence from Dhaka Export Processing Zone", ILO Conference on 'Regulating for Decent Work, held at the International Labour Office, Geneva during July 8-10. 1-8 
INTERNATIONAL JOURNAL OF ACADEMIC RESEARCH IN BUSINESS AND SOCIAL SCIENCES

Vol. 10, No. 4, April, 2020, E-ISSN: 2222-6990 @ 2020 HRMARS

\section{APPENDIX I}

Table 4.1: Assess the extent that proactive human resource management has helped to improve employee quality of work life in organizations in Southern Nigeria

\begin{tabular}{|c|c|c|c|c|c|c|c|}
\hline & & SA & $A$ & UN & $\mathrm{DA}$ & SDA & MS \\
\hline 1 & $\begin{array}{l}\text { Proactive human resource management have not made } \\
\text { significant improvement in the employee quality of } \\
\text { work life in the selected organizations in Southern } \\
\text { Nigeria }\end{array}$ & 261 & 244 & 17 & 70 & 35 & 4.0 \\
\hline 2 & $\begin{array}{l}\text { Proactive human resource management have made } \\
\text { very insignificant improvement in the employee quality } \\
\text { of work life in the selected organizations in Southern } \\
\text { Nigeria }\end{array}$ & 225 & 242 & 24 & 72 & 64 & 3.78 \\
\hline 3 & $\begin{array}{l}\text { Proactive human resource management have made } \\
\text { very little improvement in the employee quality of } \\
\text { work life in the selected organizations in Southern } \\
\text { Nigeria }\end{array}$ & 277 & 251 & 18 & 36 & 45 & 4.08 \\
\hline 4 & $\begin{array}{l}\text { Proactive human resource management have made } \\
\text { highly significant improvement in the employee quality } \\
\text { of work life in the selected organizations in Southern } \\
\text { Nigeria }\end{array}$ & 96 & 73 & 24 & 197 & 237 & 1.92 \\
\hline 5 & $\begin{array}{l}\text { Proactive human resource management have not made } \\
\text { any improvement in the employee quality of work life } \\
\text { in the selected organizations in Southern Nigeria }\end{array}$ & 74 & 46 & 18 & 268 & 221 & 2.16 \\
\hline
\end{tabular}

Source: Field Survey, 2019

\section{APPENDIX II}

Table 4.2: factors that impede proactive human resource management and avert improvement in employee QWL in the selected organizations in Southern Nigeria

\begin{tabular}{|c|c|c|c|c|c|c|c|}
\hline $\mathrm{S} /$ & & SA & A & UN & $\mathrm{DA}$ & SDA & MS \\
\hline 1 & Unsafe work Environment & 221 & 252 & 9 & 86 & 59 & 3.78 \\
\hline 2 & Inadequate and unfair compensation & 270 & 235 & 16 & 45 & 61 & 3.97 \\
\hline 3 & $\begin{array}{l}\text { Absence of Opportunity for personal growth and job } \\
\text { security }\end{array}$ & 206 & 278 & 18 & 45 & 80 & 3.77 \\
\hline 4 & $\begin{array}{l}\text { Constant infringement on personal leisure and family } \\
\text { needs }\end{array}$ & 240 & 277 & 18 & 37 & 55 & 3.97 \\
\hline 5 & $\begin{array}{l}\text { Lack of protection for personal privacy, dissent, and due } \\
\text { process }\end{array}$ & 245 & 219 & 9 & 27 & 127 & 3.68 \\
\hline
\end{tabular}

Source: Field Survey, 2019 
INTERNATIONAL JOURNAL OF ACADEMIC RESEARCH IN BUSINESS AND SOCIAL SCIENCES

Vol. 10, No. 4, April, 2020, E-ISSN: 2222-6990 @ 2020 HRMARS

\section{APPENDIX III}

Table 4.3: Impact of the improvement on employees' QWL on their attitude to work in the selected organizations in Southern Nigeria

\begin{tabular}{|l|l|l|l|l|l|l|l|}
\hline 1 & \multicolumn{1}{|c|}{ SA } & A & UN & DA & SDA & MS \\
\hline 1 & $\begin{array}{l}\text { The improvement in employees' QWL has made } \\
\text { employees in the selected organizations in Southern } \\
\text { Nigeria be conscientious in carrying out assigned duties. }\end{array}$ & 99 & 66 & 12 & 280 & 170 & 2.11 \\
\hline 2 & $\begin{array}{l}\text { The improvement in employees' QWL has improved the } \\
\text { relationships between workers and between worker and } \\
\text { managers in the selected organizations in Southern } \\
\text { Nigeria. }\end{array}$ & 78 & 10 & 148 & 300 & 2.20 \\
\hline 3 & $\begin{array}{l}\text { The improvement in employees' QWL has made the } \\
\text { workers develop high morale in discharging their duties }\end{array}$ & 18 & 163 & 25 & 185 & 236 & 2.27 \\
\hline 4 & $\begin{array}{l}\text { The improvement in employees' QWL has made the } \\
\text { workers be satisfied with their work in the selected } \\
\text { organizations in Southern Nigeria }\end{array}$ & 31 & 19 & 331 & 204 & 2.00 \\
\hline 5 & $\begin{array}{l}\text { The improvement in employees' QWL has reduced level } \\
\text { of workers' lateness and absenteeism in the selected } \\
\text { organizations in Southern Nigeria }\end{array}$ & 36 & 0 & 331 & 231 & 1.90 \\
\hline
\end{tabular}

Source: Field Survey, 2019 